\title{
Effect of Probiotics on production and egg quality of dual purpose chicken at Kathmundu in Nepal
}

\author{
Neupane $D^{1 *}$, DB Nepali ${ }^{2}$, N Devkota ${ }^{2}$, MP Sharma² and IP Kadaria²
}

${ }^{1}$ Swine and Avian Research Program, Khumaltar, NARC, Nepal; ${ }^{2}$ Agriculture and Forestry University, Chitwan, Nepal

\begin{abstract}
A total of 448, Sakini (224) and Giriraja (224) breed of chickens were used to investigate the feed intake $\&$ weight gain from $0-150$ days and egg production and egg quality from 150 - 240 days of age in Khumaltar Lalitpur Nepal. The four different levels of probiotics viz. 0,5, 10 and $15 \mathrm{ml}$ of Probiotic (Poultry biosa)/kg of feed were used with randomized factor design $2 * 4 * 8$ (RBD) with 8 treatments and 8 replications. The data was recorded daily on feed intake and egg production and in every 15 days interval for weight gain. Results showed that the addition of probiotic to the feed significantly improved feed intake, weight gain, egg production and egg quality on sakini and giriraja breeds of chickens $(P<0.05)$. Additionally, data on egg production and egg quality showed increased production in treatment group than control group $(P<0.05)$. The general trend revealed increasing level of egg production from five to eight months with significant difference $(P<0.05)$. Nutrient analysis of eggs by proximate analysis in terms of $\mathrm{CP}, \mathrm{CF}$, fat and energy showed significant difference $(P<0.05)$. Thus to conclude, there is positive effect of probiotics for production and productivity in terms of feed conversion ratio, weight gain, egg production \& egg quality in Sakini and Giriraja breed of Chicken.
\end{abstract}

Key words: Probiotic, Sakini, Giriraja, Feed intake, Weight gain, Egg production, Egg quality

Bangladesh Animal Husbandry Association. All rights reserved.

Bang. J. Anim. Sci. 2019. 48 (1):29-35

\section{Introduction}

Poultry production is an important and diverse component of agriculture all over the world (Kabir et al., 2004). In large-scale rearing facilities, where poultry are exposed to stressful conditions, problems related to diseases and deterioration of environmental conditions often occur and result in to serious economic losses (Jin et al, 1998). Prevention and control of diseases have led during recent decades to a substantial increase in the use of veterinary medicines. However, the utility of antimicrobial agents as a preventive measure has been questioned, given extensive documentation of the evolution of antimicrobial resistance among pathogenic bacteria (Jin et al., 1998). So, the possibility of antibiotics ceasing to be used as growth stimulants for poultry and the concern about the side-effects of their use as therapeutic agents has produced a condition in which both consumer and manufacturer are looking for alternatives. Probiotics are being considered to fill this gap and already some farmers are using them in preference to antibiotic (Kalavathy et al., 2003). Adding the so-called beneficial bacteria to the digestive tract of poultry is not a new concept, however, a complete understanding of where, when and how to use them still has a subject of research. A strikingly crucial event in the development of probiotics was the finding that newly hatched chickens could be protected against colonization by Salmonella enteritidis by dosing a suspension of gut contents derived from healthy adult chickens (Mountzouris et al., 2007). However, a complete understanding of where, when and how to use them still has escaped us in especially in the context of developing countries like Nepal. Thus the present study was done using four different levels of probiotics $(0,5,10$ and $15 \mathrm{ml}$.) in two different breeds of chickens viz. Sakini and Giriraja with the objective to assess the effect of probiotics for feed conversion, weight gain, egg production \& egg quality in Sakini \& Giriraja breed of chicken.

\section{Materials and Methods}

\section{Experimental design and bird management}

A total of 448 day-old chicks of Sakini and Giriraja breed in the farm of SARP, Khumaltar were used for experiment. The design of the experiment was randomized factor design $2 * 4 * 8$ (RBD) with 8 treatments and 8 replications. There were 64 experimental units and each experimental unit comprised 7 birds. The size for each cage was $4 * 3$ feet. The birds were provided ad libtum feed as recommended for different age

*Corresponding author: damodarneupane@ymail.com 
group. These were evaluated for Feed Conversion ratio, weight gain, egg production \& egg quality.

\section{Data collection and Statistical analysis}

The body weight of each experimental bird was collected fortnightly and the feed consumption \& egg collection record were done daily. The treatment with probiotic (poultry Biosa) at different level was considered as independent factor and the feed intake, body weight and FCR were taken as dependent factor. Data was analysed following the general linear model (one way ANOVA) procedure of SPSS ver20.0 and the post-hoc comparison of means was made using Duncan's multiple range test. Significance was considered at $P<0.05$.

\section{Results \& Discussion}

\section{Feed Intake, weight gain and FCR for 0-60 days}

Table 1. ANOVA table for feed intake, Weight gain and FCR for 0-60 days

\begin{tabular}{|c|c|c|c|}
\hline $\begin{array}{l}\text { Treatment } \\
\text { No. }\end{array}$ & $\begin{array}{l}\text { Feed Intake in Kg. } \\
\quad(\text { mean } \pm S E)\end{array}$ & Weight in Kg. (mean \pm SE) & FCR \\
\hline 1 & $9.57 \pm 1.59^{\mathrm{cd}}$ & $3.3 \pm 0.89^{d}$ & 2.9 \\
\hline 2 & $8.08 \pm 1.51^{d}$ & $3.3 \pm 0.44^{d}$ & 2.4 \\
\hline 3 & $10 \pm 2.60^{c}$ & $4.16 \pm 0.56^{c}$ & 2.4 \\
\hline 4 & $9 \pm 0.14^{d}$ & $3.24 \pm 0.74^{\mathrm{d}}$ & 2.7 \\
\hline 5 & $19 \pm 0.71^{\mathrm{b}}$ & $7 \pm 0.17^{b}$ & 2.5 \\
\hline 6 & $17.75 \pm 0.27^{\mathrm{b}}$ & $7.1 \pm 0.61^{b}$ & 2.5 \\
\hline 7 & $19 \pm 0.15^{\mathrm{a}}$ & $8.2 \pm 0.31^{a}$ & 2.3 \\
\hline 8 & $19.92 \pm 8.3^{\mathrm{a}}$ & $8.3 \pm 0.97^{a}$ & 2.3 \\
\hline P Vallue & 0.000 & 0.01 & \\
\hline Level of Sig. & $* *$ & $* *$ & \\
\hline
\end{tabular}

Note: $\mathrm{SE}=$ Standard error , $\mathrm{FCR}=$ Feed Conversion ratio $* *=$ level of significance at $95 \%$

Results from the study from day 0-60 revealed that there is no significant difference $(P<0.05)$ for weight gain and FCR but there is significant effect for feed intake with different level of treatment with Biosa. As T8 (Biosa -15 ml) for Giriraja and T3( Biosa- 10ml) for Sakini has shown the highest level of feed intake and the (T6 and T7/ Giriraja) and (T1 and T2 / Sakini) has shown the lowest level for the same. Similarly, T1/Giriraja
(Control )and T3 /Sakini (Biosa-10ml)showed highest level of weight gain and T6/ Giriraja( Biosa-10ml) and T4 Sakini (Biosa-10ml) group showed the lowest weight gain. The highest value for FCR was observed in T7/Giriraja group(Biosa$10 \mathrm{ml}$ ) and T4/ Sakini group (Biosa-15ml) and the lowest FCR value was observed in T6/ Giriraja(Biosa-5ml) and T2/ Sakini group (Biosa$5 \mathrm{ml})$.

\section{Feed Intake, weight gain and FCR for 61-90 days.}

Table 2. ANOVA table for feed intake, Weight and FCR for 61-90 days

\begin{tabular}{cccc}
\hline $\begin{array}{c}\text { Treatment } \\
\text { No. }\end{array}$ & $\begin{array}{c}\text { Feed Intake in Kg. } \\
\text { (mean } \pm \text { SE) }\end{array}$ & $\begin{array}{c}\text { Weight in Kg } \\
\text { (mean } \pm \text { SE) }\end{array}$ & FCR \\
\hline 1 & $14.62 \pm .082^{\mathrm{b}}$ & $4.0 \pm 0.01^{\mathrm{bc}}$ & 3.25 \\
2 & $12.02 . \pm 0.83^{\mathrm{c}}$ & $4.25 \pm 0.08^{\mathrm{c}}$ & 2.83 \\
3 & $12.14 \pm .0 .55^{\mathrm{bc}}$ & $4.4 \pm 0.08^{\mathrm{c}}$ & 2.76 \\
4 & $11.84 \pm 0.19^{\mathrm{b}}$ & $4.10 \pm 0.10^{\mathrm{bc}}$ & 2.89 \\
5 & $28.67 \pm 0.94^{\mathrm{ab}}$ & $9 . .72 \pm 0.03^{\mathrm{b}}$ & 2.95 \\
6 & $25.76 \pm 0.09^{\mathrm{a}}$ & $11.20 \pm 0.14^{\mathrm{a}}$ & 2.30 \\
7 & $25.76 \pm 0.69^{\mathrm{a}}$ & $11.29 \pm 0.06^{\mathrm{a}}$ & 2.28 \\
8 & $29.32 \pm 0.18^{\mathrm{a}}$ & $11.50 \pm 0.07^{\mathrm{a}}$ & 2.55 \\
\hline P value & .000 & .04 & \\
Leve I of sig. & $* *$ & $* *$ &
\end{tabular}


Neupane et al. (2019) Bang. J. Anim. Sci. 2019. 48 (1):29-35

Results from the study from day 61 -90 days revealed that there is significant difference $(P<0.05)$ for feed intake, weight gain and FCR with different level of treatment with Biosa. As T8 and T7 (Biosa $-15 \mathrm{ml}$ and $10 \mathrm{ml}$ ) for Giriraja and T3( Biosa- 10ml) for Sakinihas shown the highest level of feed intake and the T6 and T7/ Giriraja( Biosa- $5 \mathrm{ml}$ and $10 \mathrm{ml}$ ) and (T1 and T2 / Sakini( control and Biosa- $10 \mathrm{ml}$ ) has shown the lowest level for the same.Similarly, T8/Giriraja( Biosa- 15ml) and T3 /Sakini( Biosa- 10ml) showed highest level of weight gain and T5/ Giriraja ( Control) and T1Sakini group ( Control) showed the lowest level of weight gain. The highest value for FCR was observed in T7/Giriraja group and T4/ Sakini group and the lowest FCR value was observed in T6/ Giriraja( Biosa-5ml) and T3/ Sakini ( Biosa-10 ml) group

\section{Feed Intake, weight gain and FCR for 91-120 days.}

Table 3. ANOVA table for feed intake, Weight and FCR for 91-120 days

\begin{tabular}{|c|c|c|c|}
\hline $\begin{array}{l}\text { Treatment } \\
\text { no. }\end{array}$ & Feed Intake in $\mathrm{Kg} .($ mean \pm SE) & $\begin{array}{l}\text { Weight in } \mathrm{Kg} . \\
(\text { mean } \pm \mathrm{SE})\end{array}$ & FCR \\
\hline 1 & $21.25 \pm 0.82^{\mathrm{C}}$ & $6.5 \pm 0.08^{\mathrm{bc}}$ & 3.27 \\
\hline 2 & $19.26 \pm 0.83^{c}$ & $6.4 \pm 0.10^{c}$ & 3.01 \\
\hline 3 & $21.73 \pm 0.55^{\mathrm{bc}}$ & $6.9 \pm 0.08^{c}$ & 3.10 \\
\hline 4 & $21 . .73 \pm 0.19^{b}$ & $6.9 \pm 0.05^{\mathrm{bc}}$ & 3.15 \\
\hline 5 & $43.66 \pm 0.94^{\mathrm{a}}$ & $14.8 \pm 0.32^{b}$ & 2.95 \\
\hline 6 & $39.32 \pm 0.94^{\mathrm{a}}$ & $14.3 \pm 0.14^{\mathrm{a}}$ & 2.75 \\
\hline 7 & $41.78 \pm 0.69^{\mathrm{ab}}$ & $15.14 \pm .06^{\mathrm{ab}}$ & 2.76 \\
\hline 8 & $41.86 \pm 0.18^{a}$ & $15.28 \pm .07^{a}$ & 2.74 \\
\hline $\begin{array}{l}\text { P value } \\
\text { Level of sig. }\end{array}$ & $\begin{array}{l}.00 \\
* *\end{array}$ & $\begin{array}{l}.04 \\
* *\end{array}$ & \\
\hline \multicolumn{4}{|c|}{ Note: $\mathrm{SE}=$ Standard Error, $* *=$ Significant at $0.5 \%$ level, $\mathrm{FCR}=$ Feed conversion ratio } \\
\hline \multicolumn{2}{|c|}{$\begin{array}{l}\text { Results of the study from } 91-120 \text { days revealed } \\
\text { that there is significant difference }(P<0.05 \text { ) for } \\
\text { feed intake and weight gain with different level of } \\
\text { treatment with Biosa. As T8 (Biosa }-15 \mathrm{ml} \text { ) for } \\
\text { Giriraja and T2(Biosa- } 5 \mathrm{ml} \text { ) for Sakinihas shown } \\
\text { the highest level of feed intake and the } \\
\text { T5Giriraja (Control group) and T3 / Sakini( Biosa- } \\
10 \mathrm{ml} \text { ) has shown the lowest level for the } \\
\text { same.Similarly, T8/Giriraja(Biosa- } 15 \mathrm{ml} \text { ) and T3 }\end{array}$} & \multicolumn{2}{|c|}{$\begin{array}{l}\text { /Sakini( Biosa- } 10 \mathrm{ml} \text { ) showed highest level of } \\
\text { weight gain and T5/ Giriraja ( Control) and T1 } \\
\text { Sakini group ( Control) showed the lowest level of } \\
\text { weight gain. The highest value for FCR was } \\
\text { observed in T8/Girirajagroup ( Biosa-15ml) and } \\
\text { T4/ Sakini group and the lowest FCR value was } \\
\text { observed in T6/ Giriraja( Biosa-5ml) and T2/ } \\
\text { Sakini (Biosa-5 ml) group. }\end{array}$} \\
\hline
\end{tabular}

Feed Intake, weight gain and FCR for 121-150 days.

Table 4: ANOVA table for feed intake, Weight gain and FCR for 91-120 days

\begin{tabular}{lccc}
\hline Teatment & Feed Intake (mean \pm SE) & Weight (mean \pm SE) & FCR \\
\hline 1 & $32.90 \pm 0.83^{\mathrm{b}}$ & $9.40 \pm 0.03^{\mathrm{c}}$ & 3.5 \\
2 & $32.64 \pm 0.80^{\mathrm{b}}$ & $9.60 \pm 0.04^{\mathrm{c}}$ & 3.4 \\
3 & $33.46 \pm 0.09^{\mathrm{b}}$ & $10.65 \pm 0.05^{\mathrm{c}}$ & 3.45 \\
4 & $33.46 \pm 0.03^{\mathrm{b}}$ & $9.70 \pm 0.03^{\mathrm{c}}$ & 3.45 \\
5 & $52.75 \pm 0.64^{\mathrm{a}}$ & $15.47 \pm 0.14^{\mathrm{b}}$ & 3.41 \\
6 & $54.19 \pm 0.13^{\mathrm{a}}$ & $16.78 \pm 0.11^{\mathrm{b}}$ & 3.23 \\
7 & $52.63 \pm 0.41^{\mathrm{a}}$ & $17.2 \pm 0.13^{\mathrm{a}}$ & 3.06 \\
8 & $54.27 \pm 0.50^{\mathrm{a}}$ & $18.09 \pm 0.03^{\mathrm{a}}$ & 3.0 \\
\hline P value & 0.000 & & \\
Level of significance & $* *$ & $* *$ &
\end{tabular}


Results from the study from $121-150$ days revealed that there is significant difference $(P<0.05)$ for feed intake and weight gain with different level of treatment with Biosa. As T8(Biosa -15 ml) for Giriraja and T2( Biosa- 5ml) for Sakinihas shown the highest level of feed intake and the T5Giriraja( Control group) and T1 / Sakini( Control) has shown the lowest level for the same.Similarly, T8/Giriraja ( Biosa- 15ml) and T3 /Sakini( Biosa- 10ml) showed highest level of weight gain and T5/ Giriraja ( Control) and T1 Sakini group ( Control) showed the lowest level of weight gain. The highest value for FCR was observed in T6/Giriraja group ( Biosa-ml) and T3/ Sakini group and the lowest FCR value was observed in T8/ Giriraja( Biosa-15ml) and T4/ Sakini ( Biosa-15 ml) group.

Results from this study revealed that there is significant effect of probiotics $(P<0.05)$ for feed intake, weight gain and FCR except early 60 days.The Probiotic incorporated @ $15 \mathrm{ml}$ has shown the highest level of intake, weight and FCR compared to other treatents and control. The finding is in line with different reserachers. As, Pelicano et al. (2004) used two commercial probiotics, the first composed with Bacillus subtilis (150 $\mathrm{g} /$ ton feed) and the second with Lactobacillus acidophilus and casei, Streptococcus lactis and faecium, Bifidobacterium bifidum and Aspergillus oryzae ( $1 \mathrm{~kg} /$ ton feed) for broilers in the period of one to 14 days of age and observed an improvement in feed conversion up to 21 days of age in animals receiving probiotics, regardless of the composition, in relation to the group without any addition. Cao et al. (2013) found that supplementation the broiler diets with a single strain of Lactobacillus (Enterococcus faecium) significantly improved the BW and BWG compared to the control. Kalavathy et al. (2003) found an improvement in body weight gain (BWG) and feed conversion ratio (FCR) of broilers fed a mixture of different Lactobacillus strains from 1 to 42 days of age. Similarly, Improvement in the performance of broilers has been reported by several researchers (Dilworth \& Day, 1978; Jin et al., 1996; Mohan et al., 1996; Yeo \& Kim, 1997; Santoso et al. 1995; Jin et al., 1998a; Cuevas et al., 2000; Fritts et al.,2000; Kabir et al., 2004; Huang et al., 2004; Schocken-Iturrino et al., 2004; Gil de los Santos et al., 2005; Mountzouris et al., 2007; Rigobelo et al., 2011). However, some contrasting results are obtained by (Loddi et al. 2000; Lima et al. 2003; Willis \& Reid, 2008) have not shown any benefit for the use of probiotics in any breeding phase of broilers. This might be due to duration, little knowledge on minimum required dose and various others. As, Siriken et al. (2003), stated that the duration of treatment can be an important factor in the effect of a probiotic on the intestinal microbiota, once probiotics can be given only once or periodically, in weekly or daily intervals. Similarly, (Cole \& Fuller, 1984; Goldin \& Gorbach, 1984) also agreed that the little knowledge regarding the minimum required dose to evidence the effects of probiotics, experiments in mice, humans and pigs have indicated that the effect decreases when the probiotic is discontinued

Additionally, Giriraja Breed has shown the highest level of feed intake, weight gain and FCR compared to Sakini has shown the lowest for the same within the given duration of the experiment. The findings agrees with that of Aryal and Neopane (1997) as they observed 2.8 and 3.68 FCR for Giriraja and New Hampshire respectively. Similarly, Ramappa and Loknath (1985) reported 2.4 FCR value for Giriraja in India. The variation might be due to the duration of experimentation (0-150 days). Variations on the Efficacy of Probiotics in Poultry 213the diet of animals and have not found differences among the treatments in relation to body weight gain, feed conversion rate and carcass yield.

\section{Egg production}

Similarly, egg production and egg qualities were also observed for 150-180 days revealed different results.

\section{Trends of production}

The general growth trend for egg production for the given period of experimentation( 5-8 months) have been illustrated by the Table $\mathbf{5}$. 
Neupane et al. (2019) Bang. J. Anim. Sci. 2019. 48 (1):29-35

Table 5. ANOVA table for egg production.

\begin{tabular}{|c|c|c|c|}
\hline Treatment & Mean \pm SE(6 months $)$ & Mean \pm SE(7 months $)$ & Mean \pm SE(8 months) \\
\hline 1 & $15.50 \pm 0.64$ & $15.50 \pm 0.64$ & $17.25 \pm 0.85$ \\
\hline 2 & $15.25 \pm 0.47$ & $15.25 \pm .047$ & $16.25 \pm 0.47$ \\
\hline 3 & $14.75 \pm 1.25$ & $14.75 \pm 1.25$ & $15.75 \pm 1.25$ \\
\hline 4 & $16.50 \pm 0.64$ & $16.50 \pm 0.64$ & $17.50 \pm 0.64$ \\
\hline 5 & $15.00 \pm 1.22$ & $15.00 \pm 1.22$ & $16.00 \pm 1.22$ \\
\hline 6 & $16.00 \pm 0.70$ & $16.00 \pm 0.70$ & $17.00 \pm 0.70$ \\
\hline 7 & $16.75 \pm 1.10$ & $16.75 \pm 1.10$ & $17.75 \pm 1.10$ \\
\hline 8 & $16.25 \pm 0.85$ & $16.25 \pm 0.85$ & $17.25 \pm 0.85$ \\
\hline$P$ value & 0.710 & 0.718 & 0.718 \\
\hline Level of significance & NS & NS & NS \\
\hline
\end{tabular}

The pattern shows that there is general increasing trend from 5 to 8 month. No significant difference was observed $(P<0.05)$ till the period of experimentation. However, the lowest production was recorded during $5^{\text {th }}$ month followed by increasing trend. The highest mean production was recorded from T8 (Giriraja-15 ml) and T4 (Sakini- $15 \mathrm{ml}$ ) probiotic. However, the lowest production was recorded during $6^{\text {th }}$ month followed by increasing trend. The highest mean production was recorded from T8 (Giriraja-15 ml) and T4 (Sakini- $15 \mathrm{ml}$ ) probiotic.The findingsdisagrees the findings of different researcherasMulder et al.1997)reported that inoculation with a probiotic strain of $L$. reuterisignificantly increased the number of eggs in layer chickens. A similar finding was presented by $L n$ et al. (2003) with a mixture of $L$. acidophilus/gallinarum, Lactobacillus agilis, $L$. salivarius, and Lactobacillus spp.The exact reason for the variation could not be explored however results of research available in literature with the use of probiotics are very variable, once several factors can interfere such as type of probiotic, its action mode, its interaction with the host and breeding environment.

\section{Egg quality parameters}

The eggs from different groups were evaluated for egg internal quality using proximate analysis and the data have been illustrated by the table below.

Table 6. ANOVATable for egg quality parameters

\begin{tabular}{lccccc}
\hline Treatment & Total eggs set & Fertility & Fertility $\%$ & Hatchability & Hatchability \% \\
\hline T1 & 28 & 18 & 64.88 & 15 & 53 \\
T2 & 37 & 29 & 78 & 25 & 67 \\
T3 & 57 & 52 & 91 & 20 & 35 \\
T4 & 53 & 36 & 67 & 27 & 50 \\
T5 & 51 & 44 & 86 & 33 & 64 \\
T6 & 51 & 46 & 90 & 41 & 80 \\
T7 & 49 & 90 & 27 & 47 \\
T8 & 54 & 81 & 30 & 46 \\
\hline
\end{tabular}

The fertility and hatchability have been presented in terms of percentage. There is variation in the result, however the result of T6Biosa- $10 \mathrm{ml}$ seems better than other groups. The exact reasen could not be explored however breed effect might be the reason.

\section{Nutrient content of Egg}

Study on nutrient content of egg was done with proximate analysis using standard protocol. The results have been given as under table. 
Table 7..ANOVA table for Study on Nutrient content of Egg

\begin{tabular}{|c|c|c|c|c|c|c|}
\hline Treatment & $\begin{array}{c}\text { FDM } \\
(\text { mean } \pm S E)\end{array}$ & $\begin{array}{c}\text { OM } \\
(\operatorname{mean} \pm S E)\end{array}$ & $\begin{array}{c}\text { T.Ash } \\
\text { (mean } \pm \text { SE) }\end{array}$ & $\begin{array}{c}\text { CP } \\
(\text { mean } \pm S E)\end{array}$ & $\begin{array}{c}\text { CF } \\
(\text { mean } \pm S E)\end{array}$ & $\begin{array}{c}\text { EE } \\
(\operatorname{mean} \pm S E)\end{array}$ \\
\hline $\mathrm{T} 1$ & $\begin{array}{c}5.5700 \\
\pm .48951^{c}\end{array}$ & $\begin{array}{c}98.8050 \pm \\
.11722^{c}\end{array}$ & $\begin{array}{l}1.1950 \pm \\
.11722^{\mathrm{a}}\end{array}$ & $\begin{array}{c}22.9675 \pm \\
.96100^{a}\end{array}$ & $\begin{array}{l}4.6775 \pm \\
.58036^{\mathrm{ab}}\end{array}$ & $\begin{array}{l}2.9800 \pm \\
.12430^{a}\end{array}$ \\
\hline $\mathrm{T} 2$ & $\begin{array}{c}14.0125 \pm \\
.25753^{a b}\end{array}$ & $\begin{array}{c}98.8500 \pm \\
.11262^{c}\end{array}$ & $\begin{array}{c}1.1500 \pm \\
.11262^{\mathrm{a}}\end{array}$ & $\begin{array}{c}24.6675 \pm \\
1.20384^{a}\end{array}$ & $\begin{array}{l}5.1525 \pm \\
.44541^{\mathrm{bc}}\end{array}$ & $\begin{array}{l}3.2775 \pm \\
.18377^{\mathrm{ab}}\end{array}$ \\
\hline T3 & $\begin{array}{c}13.3575 \pm \\
.37292^{\mathrm{a}}\end{array}$ & $\begin{array}{c}98.9175 \pm \\
.09205^{c}\end{array}$ & $\begin{array}{l}1.0825 \pm \\
.09205^{a}\end{array}$ & $\begin{array}{c}25.7200 \pm \\
.44913^{a}\end{array}$ & $\begin{array}{l}5.2650 \pm \\
.46638^{\mathrm{bc}}\end{array}$ & $\begin{array}{l}3.1875 \pm \\
.24787^{a}\end{array}$ \\
\hline T5 & $\begin{array}{c}13.9125 \pm \\
.25591^{\mathrm{ab}}\end{array}$ & $\begin{array}{c}98.7600 \pm \\
.08765^{c}\end{array}$ & $\begin{array}{l}1.1450 \pm \\
.10186^{a}\end{array}$ & $\begin{array}{c}26.3650 \pm \\
.44636^{a}\end{array}$ & $\begin{array}{r}3.9375 \pm \\
.12990^{a}\end{array}$ & $\begin{array}{l}3.7675 \pm \\
.15750^{\mathrm{bc}}\end{array}$ \\
\hline T6 & $\begin{array}{l}13.9500 \pm \\
.20244^{\mathrm{ab}}\end{array}$ & $\begin{array}{c}98.6700 \pm \\
.04882^{\mathrm{bc}}\end{array}$ & $\begin{array}{l}1.3275 \pm \\
.04854^{\mathrm{ab}}\end{array}$ & $\begin{array}{c}26.4150 \pm \\
.27810^{\mathrm{ab}}\end{array}$ & $\begin{array}{l}3.9700 \pm \\
.20166^{\mathrm{ab}}\end{array}$ & $\begin{array}{l}3.8675 \pm \\
.13536^{\mathrm{bc}}\end{array}$ \\
\hline$P$ value & 0.004 & 0.001 & 0.011 & 0.022 & 0.038 & 0.00 \\
\hline $\begin{array}{c}\text { Level of } \\
\text { Significance }\end{array}$ & $* *$ & $* *$ & $* *$ & $* *$ & $* *$ & $* *$ \\
\hline
\end{tabular}

Note: $\mathrm{SE}=$ Standard Error, $* *=$ Significant at $0.5 \%$ level, $*=$ Significant at $0.1 \%$ level

Results from this study revealed that there is significant difference $(P<0.05)$ for different nutritional traits. The effect of treatment seems to increase the nutrient content in both the breeds.( FDM, OM, CP, Cf and EE).

The findings agrees with that of Mulder et al.(1997) as he reported that inoculation with a probiotic strain of $L$. reuterisignificantly increased the number and quality of eggs in layer chickens. A similar finding was presented by Lnetal. (2003) with a mixture of L.acidophilus/gallinarum, Lactobacillusagilis, Ls alivarius, and Lactobacillus spp.

\section{Conclusion}

The feed intake, weight gain, Feed conversion ratio(FCR)\& egg quality on $10-15 \mathrm{ml} / \mathrm{kg}$ feed probiotic supplemented group found to be significantly superior in Giriraja and Sakinibreed of chicken. Similarly,significantly increased the number and quality of eggs on both the breeds. So, Present study revealed that Giriraja and Sakini breeds have potential effect on supplementation of Probiotic on feed. Giriraja breed showed better performance than Sakini in termsof higher growth, better feed efficiency and saving per birds. 
Neupane et al. (2019) Bang. J. Anim. Sci. 2019. 48 (1):29-35

\section{Acknowledgement}

The author is extremely thankful to all the staffs of Swine \& Avian Research Program of Nepal Agricultural Research Council (NARC) who had helped a lot during experimentation.

\section{References}

Pelicano, E.R.L.; Souza, P.A.; Souza, H.B.A; Leonel, F.R.; Zeola, N.M.B.L. \&Bonago, M.M. (2004). Productive Traits of Broiler Chickens Fed Diets Containing Different Growth Promoters. Brazilian Journal of Poultry Science, Vol.6, No.3, (September 2004), pp.177-182 ISSN 1516$635 x$

Kalavathy R, Abdullah N, Jalaludin S, Ho YW. Effects of Lactobacillus cultures on growth performance, abdominal fat deposition, serum lipids and weight of organs of broiler chickens. Br. Poult. Sci. 2003;44:139-144

Dilworth, B.C. \& Day, E.J. (1978). Lactobacillus cultures in broiler diets (S.A.A.S. Abstract). Poultry Science, Vol.57, No.4, (July 1978), pp. 1101, ISSN 1525-3171

Jin LZ, Ho YW, Abdullah N, Jalaludin S. Growth performance, intestinal microbial populations and serum cholesterol of broilers fed diets containing Lactobacillus cultures. Poult. Sci. 1998;77:1259-1265

Jin, L.Z.; Ho, Y.W.; Abdullah, N. \&Jalaludin, S. (1996). Influence of dried Bacillus subtilis and Lactobacilli cultures on intestinal microflora and performance in broiler. Asian-Australasian
Journal of Animal Science, Vol.9, No.4, (August 1996), pp. 397-404, ISSN 1076-5517

Mohan, N.; Kadirvel, R.; Natarajan, A. \&Bhaskaran, M. (1996). Effect of probiotic supplementation on growth, nitrogen utilisation and serum colesterol broilers. British Poultry Science, Vol.37, No.2, pp. 395-401, ISSN 1466-1799

Cuevas, A.C.; Gonzales, E.A.; Huguenin, M.C.; \&Domingues, S.C. (2000). El efecto del Bacillustoyoiisobre el comportamiento productivo en pollos de engorda. VeterináriaMéxico, Vol.31, No.4, 05.04.2012,

Fritts, C.A.; Kersn, J.H.; Motl, M.A.; Kroger, E.C.; Yan, E.; Si, J.; Jiang, Q.; Campos, M.M.; Waldroup, A.L. \&Waldroup, P.W (2000). Bacillus subtilis C-3102 (Calsporin) improves live performance and microbiological status of broiler chickens. Journal of Applied Poultry Research, Vol.9, No.2, (January 2000), pp. 149155, ISSN 1537-0437

Kabir, S.M.L.; Rahman, M.M.; Rahman, M.B. \& Ahmed S.U. (2004). The dynamic of probiotics on growth performance and immune response in broiler. International Journal of Poultry Science, Vol.3, No. 5, (May 2004), pp. 361-364, ISSN 1682-8356

Mountzouris KC, Tsirtsikos P, Kalamara E, Nitsch S, Schatzmayr G, Fegeros K. Evaluation of the efficacy of probiotic containing Lactobacillus, Bifidobacterium, Entero coccus, and Pediococcus strains in promoting broiler performance and modulating cecalmicroflora composition and metabolic activities. Poult. Sci. 2007;86:309-317 